\title{
EDUKASI PETANI TERHADAP PENCEMARAN UDARA PADA SKALA RUMAH TANGGA (HOUSEHOL AIR POLLUTION) DI DESA TRIDANA MULYA
}

\author{
Sumarlin ${ }^{1 *}$ \\ ${ }^{1}$ Program Studi Teknik Lingkungan, Fakultas Teknik, Universitas Muhammadiyah Kendari, \\ Jl. KH. Ahmad Dahlan No. 10 Kendari - Sulawesi Tenggara, Indonesia.

\section{*Corresponding Author: sumarlin@umkendari.ac.id}

Received: August 10, 2021

Received in revised: August 23, 2021

Accepted: August 23, 2021

Available online: August 31, 2021

\begin{abstract}
Knowledge offarming communities in Desa Tridana Mulya before and afterhousehold air pollution (HAP) is described in this study. Using quantitative methods, generally farmers' knowledge about air pollution on a household still low (low category 60\%; medium 3\%; high 5\%). One alternative to increase the knowledge of these farmers is through counseling activities on air pollution in the household. After the knowledge extension activities, the farmers categorized as high as $70 \%$, medium $25 \%$ and low $5 \%$ ). Shows Spearman's correlation test that $P$-value $=0.005$ is smaller than the $\alpha$ value $=0.01$, so $H_{0}: \rho s=0$ is rejected, this meaning knowledge of the farming community before and after being given counseling a significant correlation. Counseling can significantly. increase farmers' knowledge about air pollution household (HAP).
\end{abstract}

Keywords: Knowledge, counseling, farmer, air pollution, household

Pengetahuan petani Desa Tridana Mulya sebelum dan sesudah diadakan penyuluhan pencemaran udara dalam rumah tangga (household air polution) dideskripsikan dalam penelitian ini. Pendekatan kuantitatif digunakan. Sebelum dilakukan penyuluhan pengetahuan petani tentang pencemaran udara dalam skala rumah tangga umumnya masih rendah (kategori rendah 60\%; sedang 3\%; tinggi 5\%). Alternatif untuk meningkatkan pengetahuan petani tersebut dilakukan kegiatan penyuluhan. Setelah kegiatan penyuluhan, hasil evalua si menunjukkan pengetahuan petani yang dika tegorikan tinggi sebanyak $70 \%$, sedang $25 \%$ dan rendah 5\%). Uji korelasi Spearman menunjukkan $\mathrm{P}_{\text {-value }}=0,005$ lebih kecil dari nilai $\alpha=0,01$ maka $\mathrm{H}_{0}: \rho s=0$ ditolak ini menunjukkan korelasionalyang positif dan signifikan antara penyuluhan dan pengetahuan masyarakat tani. Penyuluhan dapat meningkatkan pengetahuan petani tentang pencemaran udara pada skala rumah tangga secara signifikan.

Kata Kunci: Edukasi penyuluhan, petani, pencemaran udara, rumah tangga

\section{PENDAHULUAN}

Jumlah pengguna kompor berbahan bakar padat seperti kayu, arang, batu bara, kotoran hewan, dan sampah pertanian telah mencapai lebih dari 3 milyar orang di seluruh dunia (WHO, 2018). Emisi yang dihasilkannya menjadi penyebab pencemaran udara dalam rumah tangga (Tagle et al., 2019; Fandiño-Del-Rio et al., 2020) serta pencemaran udara ambien (Conibear et al., 2018; Chowdhury et al., 2019). Telah dilaporkan pada tahun 2017 sebanyak
1,6 juta meninggal dan 59 juta cacat sepanjang hidupnya yang dikaitkan dengan paparan pencemaran udara rumah tangga State of Global Air, (2019). Permasalahan ini umumnya terjadi di negara-negara berkembang. Menurut laporan The World Bank, (2014), lebih dari 24,5 juta keluarga di Indonesia masih bergantung pada biomassa padat untuk memasak. Sebagaimana lazimnya masyarakat pedesaan di Indonesia masyarakat di Desa Tridana Mulya, Kecamatan Landono menggunakan tungku tradisional (pawon) berbahan bakar biomassa seperti 
kayu, sampah hasil pertanian untuk memasak di rumah tangga.

Pembakaran tidak sempurna dari biomassa padat menggunakan tungku menghasilkan polutan dan gas, tetapi polutan yang sering dikaitkan dengan pencemaran udara pada rumah tangga (household air poluttion/HAP) adalah karbon monoksida dan partikulat (Pope et al., 2015; Quansah et al.,2017). Tingkat emisi pencemaran udara pada rumahtangga yang diakibatkan oleh penggunaan biomassa padat bisa mencapai 20 sampai 100 kali lebih tinggi dibandingkan dengan tingkat polusi maksimum dengan bahan bakar yang cukup bersih, misalnya LPG atau gas alam, (YDD, 2014). Penggunaan kompor LPG lebih menurunkan gas-gas polutan dibandingkan menggunakan tungku biomassa padat (Carvalho et al., 2019; Grajeda et al., 2020; Islam et al., 2021).

Penggunaan biomassa sebagai bahan bakar dapat memberikan resiko kesehatan yang serius terutama pada kalangan wanita dan anak-anak (Estévez-García et al., 2020; Ranathunga et al., 2021). Ekstrasi kayu bakar dapat menyebabkan degradasi dan deforestasi (Menghwani etal., 2019). Selain itu, resiko kesehatan pada paparan jangka panjang dapat menyebabkan meninggal saat kelahiran, kelahiran prematur, kurangnya berat badan, dan peningkatan prevalensi sejumlah penyakit kronis seperti penyakit paru obstruktif kronik, diabetes, hipertensi, penyakit kardiovaskular, stroke, paru-paru, kanker dan jenis neoplasia lainnya (Gibbs-Flournoy et al., 2018, Rajkumar et al., 2019; Pratiti et al., 2020)

Berdasarkan hal tersebut di atas, maka penting untuk mengubah paradigma masyarakat, melalui proses transferisasi pengetahuan dan inovasi tepat guna dari perguruan tinggi melalui kegiatan edukasi (penyuluhan) pencemaran udara pada rumah tangga (household air pollution). Penelitian ini bertujuan mendeskripsikan pengetahuan masyarakat petani Desa Tridana Mulya sebelum dan sesudah diadakan edukasi (penyuluhan) pencemaran udara pada rumah tangga. Adapun hipotesis penelitian yang diajukan sebagai berikut:

$\mathrm{H}_{0}: \rho=0 \quad$ (Tidak terdapat hubungan yang positif dan signifikan antara pengetahuan petani sebelum dan setelah penyuluhan)

$\mathrm{H}_{\mathrm{o}}: \rho \neq 0 \quad$ (Terdapat hubungan yang positif dan signifikan antara pengetahuan petani sebelum penyuluhan dan setelah dilakukan penyuluhan )

\section{METODOLOGI \\ Alat dan Bahan}

Penelitian ini menggunakan pendekatan kuantitaif. Data dikumpulkan melalui kuisioner (angket). Alat dan bahan yang dibutuhkan untuk mendukung kegiatan ini adalah tripod (penyagga kamera), kamera (mendokumentasikan penelitian), LCD proyektor (mempresentasikan kegiatan), GPS (menentukan koordinat lokasi penelitian), serta alat tulis. Adapun bahan yang digunakan berupa kertas HVS.

\section{Prosedur kerja}

Prosedur untuk mencapai tujuan yang diharapkan, penelitian ini menggunakan desain kuasi eksperimental pre-tes dan posttest. Metode intervensi penyuluhan teknik brainstorming (curah pendapat) digunakan dengan subyek masyarakat tani Desa Tridana Mulya. Adapun materi edukasi (penyuluhan) terdiri dari: tinjauan umum, parameter-parameter dan dampak pencemaran udara pada rumah tangga. Mekanisme evaluasi kegiatan ini melalui penilaian peningkatan pengetahuan peserta dan dilakukan uji keterampilan secara acak (random) pada peserta penyuluhan.

Edukasi (penyuluhan) ini dilakukan dalam 3 (tiga) tahapan kegiatan yaitu persiapan/pengenalan, pelaksanaan dan pemantauan dan evaluasi. Kegiatan yang dilakukan pada tahap persiapan dan pengenalan yakni melakukan proses identifikasi permasalahan, perizinan, sosialisasi dan silaturahim kepada tokoh masyarakat/agama setempat, serta mempersiapkan modul penyuluhan dan pelatihan. Kegiatan pada tahap pelaksanaan yaitu melakukan presentasi (ceramah dan curah gagasan) serta praktek dengan topik pencemaran udara dalam rumah tangga. Pada Tahap akhir kegiatan dilakukan pemantauan dan evaluasi seluruh proses kegiatan yang telah dilakukan. Pengetahuan petani sebelum dan sesudah penyelenggaraan penyuluhan dievaluasi. Instrumen evaluasinya kuisioner (angket). Hasil analisis data dari kuisioner menjadi parameter/temuan dalam kegiatan ini. Tahapan-tahapan pengukuran pengetahuan petani dalam kegiatan penyuluhan pencemaran udara tertera pada gambar berikut. 


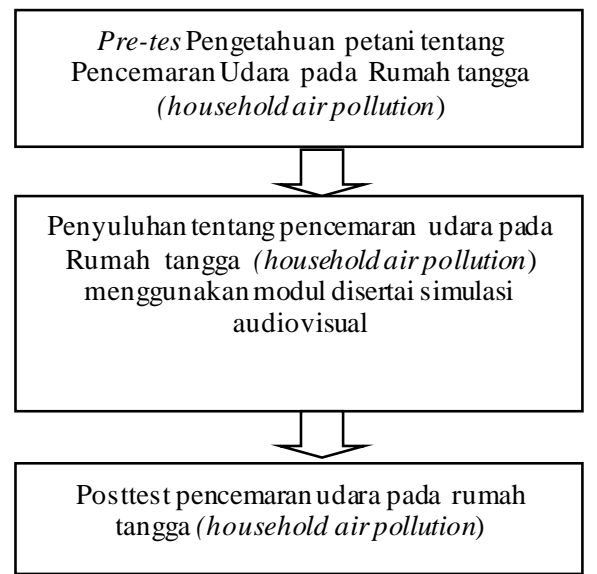

Gambar 1. Tahapan-tahapan kegiatan

\section{Analisis data}

Proses pengolahan data penelitian ini menggunakan program Microsoft office exel (MOE) 2010, program Software Statistical Package for the Social Science (SPSS . 22), dan Spearmen rho correlation

\section{HASIL DAN PEMBAHASAN}

Pengetahuan secara dominan, umumnya membentuk persepsi, perilaku dan sikap pada seseorang. Salah satu cara untuk mengukur pengetahuan seseorang dapat dilakukan dengan wawancara terstruktur (kuisioner/angket) terhadap permasalahan yang kita ingin ukur pada subyek penelitian. Pengetahuan seseorang terhadap sesuatuhal dapat diketahui dari seseorang. Tingkatan-tingkatan pengetahuan seseorang meliputi: tahu (know), memahami (compherension), aplikasi (application), analisis (analysis), sintesis (syintesis), dan evalusi (evaluation) terhadap sesuatu hal.

\section{a. Pengetahuan petani Sebelum adanya Penyuluhan pencemaran udara pada tangga (Household Air Pollution)}

Pengukuran pengetahuan masyarakat petani tentang pencemaran udara pada rumah tangga di pedesaan sebelum dilakukan penyuluhan dengan memberikan pertanyaan terstruktur (quisioner/angket). Aspek-aspek yang diukur meliputi: pemahaman umum (defenisi dan sumber) pencemaran udara pada skala rumahtangga, parameter-parameter pencemaran udara (fisik, kimia dan biologi), dan dampak pencemaran udara pada rumah tangga (kesehatan, kenyaman, dan keindahan). Pertanyaan-pertanyaan tersebut diharapkan dapat mengeksplorasi pengetahun masyarakat di Desa Tridana Mulya yang akan dijadikan dasar untuk melakukan penyuluhan dan pendampingan. Hasil pengukuran pengetahuan awal masyarakat tadi sebelum diadakan penyuluhan pada 20 orang perwakilan masyarakat tani tertera pada Tabel berikut.

Tabel 1. Pengetahuan awal masyarakat tani sebelum penyuluhan

\begin{tabular}{llcc}
\hline No & Kategori & $\begin{array}{c}\text { Jumlah } \\
\text { (orang) }\end{array}$ & $\begin{array}{c}\text { Prosentase } \\
(\%)\end{array}$ \\
\hline 1. & Tinggi & 1 & 5 \\
\hline 2. & Sedang & 7 & 35 \\
\hline 3. & Rendah & 12 & 60 \\
\hline & Jumlah & 20 & \\
\hline \multicolumn{3}{c}{ Sumber: Hasil Analisis, 2021 }
\end{tabular}

Tabel 1. menunjukkan pengetahuan masyarakat di Desa Tridana Mulya tentang pencemaran udara pada skala rumahtangga yang dikategorikan rendah sebanyak 12 orang (60\%), dikategorikan cukup 7 orang $(35 \%)$ dan yang dikategorikan baik 1 orang (5\%). Hal ini mberikan petunjuk bahwa sebagian besar masyarakat tani belum memahami pencemaran udara pada rumah tangga. Salah satu penyebabnya disinyalir masyakat tani belum mendapatkan informasi secara kompherensif tentang pencemaran udara dalam rumah tangga. Penggunaan bahan bakar biomassa padat merupakan aktivitas turun temurun untuk menyelesaikan persoalan dapur dalam rumahtangga. Selaras dengan yang dinyatakan Kusumaningrum et al., (2020) bahwa salah satu faktor yang menyebabkan rendahnya pengetahuan adalah pendidikan (faktor internal), sedangkan faktor lainnya adalah lingkungan (faktor ekternal). Gambaran pengetahuan awal masyarakat tani sebelum dilakukan penyuluhan tertera pada diagram grafik berikut ini

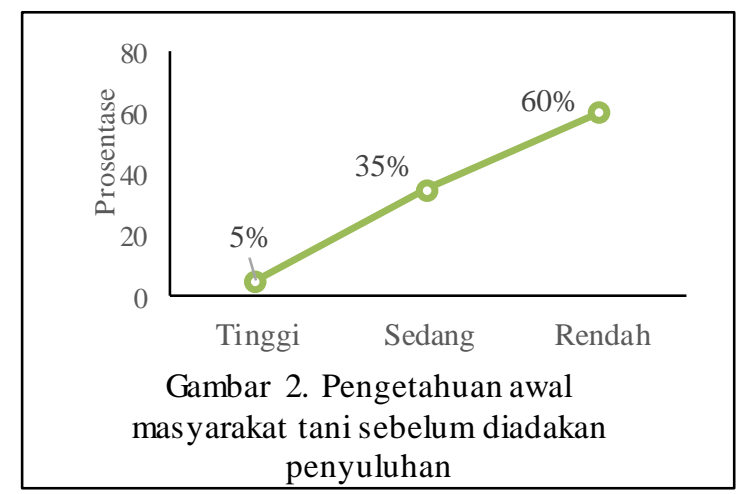

Menginterprestasi Gambar 2, tampaknya pengetahuan masyarakat akan pencemaran udara dalam rumahtangga tampaknya masih tergolong rendah. Alternatif yang dapat dilakukan untuk meningkatkan pengetahuan masyarakat tentang 
pencemaran udara tersebut yaitu melakukan edukasi (penyuluhan) yaitu proses kegiatan memanfasilitasi masyarakat dalam mendapatkan pengetahuan, informasi dan teknologi tentang pencemaran udara dalam rumah tangga.

\section{b. Pengetahuan petani setelah adanya Penyuluhan pencemaran udara pada rumah tangga (Household Air Pollution) di}

Penyuluhan pencemaran udara dalam rumah merupakan upaya dengan melakukan transfer pengetahuan dan pandangan untuk membantu dan membangun kognisi, afeksi dan psikomotor masyarakat tani dengan melalui diskusi dan simulasi agar mereka mampu mengambil keputusan secara kreatif dan mandiri terhadap keaadan di desa mereka kaitannya pencemaran udara dalam skala rumah tangga .

Bilamana pencemaran udara dalam skala rumah tangga berlangsung dalam jangka pendek maupun dalam yang lama akan berefek pada menurunnya kualitas kesehatan, estetika dan kenyamanan hidup. Secara sederhana parameter yang dapat merepresentasikan berhasil atau tidaknya kegiatan penyuluhan dapat dilihat dari perbedaan kuantisasi nilai evaluasi instrumen pengetahuan masyarakat tani sebelum dan sesudah penyuluhan. Pengetahuan masyarakat setelah penyuluhan tertera pada Tabel 2 berikut.

Tabel 2. Pengetahuan masyarakat tani setelah dilaksanakan penyuluhan

\begin{tabular}{llcc}
\hline No & Kategori & $\begin{array}{c}\text { Jumlah } \\
\text { (orang) }\end{array}$ & $\begin{array}{c}\text { Prosentase } \\
(\%)\end{array}$ \\
\hline 1. & Tinggi & 14 & 70 \\
\hline 2. & Sedang & 5 & 25 \\
\hline 3. & Rendah & 1 & 5 \\
\hline & Jumlah & 20 & \\
\hline
\end{tabular}

Sumber: Hasil Analisis, 2021

Setelah melakukan edukasi (penyuluhan), pengetahuan masyarakat tani terhadap pencemaran udara dalam rumahtangga mengalami perubahan. Seperti tertera pada Tabel 2 prosentase pengetahuan tergolong tinggi $70 \%$, sedang $25 \%$ dan rendah $5 \%$. Gambaran pengetahuan masyarakat setelah dilaksanakan penyuluhan tentang pencemaran udara pada skala rumah tangga tertera pada grafik dibawah ini.

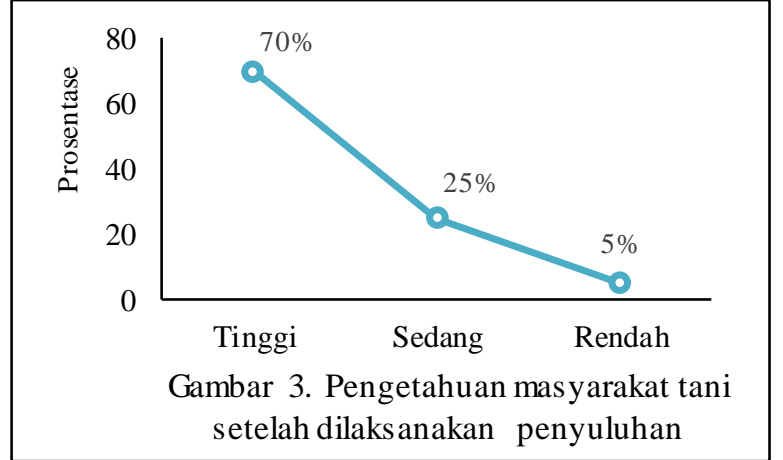

Berdasarkan Gambar 3. mayoritas masyarakat tani setelah diberikan edukasi (penyuluhan) dapat mengetahui pencemaran udara dalam rumah, sumber-sumbernya, parameterparameternya serta dampak pada kesehatan, estetiknya dan kenyamanan penghuni rumah tangga. Hal ini dapat bermanfaat untuk membentuk persepsi dan pandangan masyarakat tani terhadap pencemaran udara dalam rumahtangga dan pada akhirnya membentuk perilaku dan kebiasaan mereka.

\section{c. Peningkatan Pengetahuan petani Setelah adanya Penyuluhan pencemaran udara pada rumahtangga (Household air pollution)}

Informasi yang diperoleh dari pendidikan nonformal (penyuluhan) dapat memberikan efek jangka pendek (immediate impact) sehingga menghasilkan perubahan atau peningkatan pengetahuan. Dalam kegiatan ini, terjadinya peningkatan pengetahuan tentang pencemaran udara pada skala rumah tangga adalah nilai post tes lebih baik dari pada pre test.

Setelah kegiatan edukasi (penyuluhan), pengetahuan masyarakat di Desa Tridana Mulya tentang pencemaran udara pada rumahtangga tampak pada tiga keadaan yaitu pengetahuan masyarakat tani tergolong meningkat signifikan dari $5 \%$ menjadi $70 \%$, pengetahuan masyarakat tani kategori sedang menjadi berkurang dari $35 \%$ menjadi $25 \%$ dan pengetahuan petani kategori rendah menyusut dari $60 \%$ menjadi $5 \%$. Gambaran pengetahuan petani sebelum dan sesudah pelaksanaan penyuluhan tertera pada Tabel 3 berikut. 
Tabel 3. Perbandingan pengetahuan petani sebelum dan sesudah penyuluhan

\begin{tabular}{llcc}
\hline No & Kategori & $\begin{array}{c}\text { Sebelum } \\
\text { (orang) }\end{array}$ & $\begin{array}{c}\text { Sesudah } \\
\text { (orang) }\end{array}$ \\
\hline 1. & Tinggi & $1(5 \%)$ & $14(70 \%)$ \\
\hline 2. & Sedang & $7(35 \%)$ & $5(25 \%)$ \\
\hline 3. & Rendah & $12(60 \%)$ & $1(5 \%)$ \\
\hline \multicolumn{4}{c}{ Sumber: Hasil analisis, 2021 }
\end{tabular}

Dalam kegiatan ini pemberian edukasi (penyuluhan) tentang pencemaran udara pada rumahtangga setidaknya telah memberikan pengaruh terhadap pengetahuan masyarakat petani terkait pemahaman umum pencemaran udara, parameterparameter pencemaran udara (fisik, kimia dan biologi), dan dampak pencemaran udara pada skala rumah tangga. Gambaran peningkatan pengetahuan remaja tani sebelum dan setelah dilakukan penyuluhan pencemaranudara pada rumah di Desa Tridana Mulya dapat dilihat pada Gambar 4. berikut.

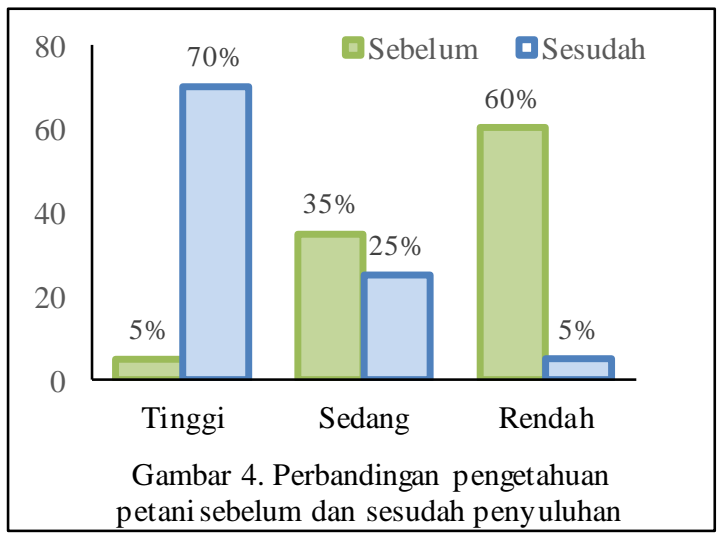

Program edukasi masyarakat melalui metode penyuluhan untuk meningkatkan pengetahuan dan sikap masyarakat terhadap pencemaran udara telah dilakukan berbagai pihak. Edukasi masyarakat melalui metode ceramah dapat meningkatkan pengetahuan dampak polusi udara. Hal ini dapat dilihat dari rata-rata nilai peserta setelah mendapatkan materi sosialisasi mengalami peningkatan (Ishak and Hadi, 2020).

Pada penelitian ini, untuk menguji korelasi pengetahuan petani sebelumdan sesudah penyuluhan pencemaran udara pada rumah tangga didasarkan nilai pree test dan post tes dan diuji menggunakan statistic Sperman rho correlation tersaji pada Tabel 3 berikut.
Tabel 4. Korelasi Spearman rho- antar nilai Pree test dan nilai Post test

\begin{tabular}{|c|c|c|c|c|}
\hline \multicolumn{5}{|c|}{ Correlations } \\
\hline & & & Preetest & Postest \\
\hline \multirow{6}{*}{$\begin{array}{l}\text { Spearman } \\
\text { 's rho }\end{array}$} & \multirow{3}{*}{ Preetest } & $\begin{array}{l}\text { Correlation } \\
\text { Coefficient }\end{array}$ & 1.000 & $.604^{* *}$ \\
\hline & & Sig. (2-tailed) & & .005 \\
\hline & & $\mathrm{N}$ & 20 & 20 \\
\hline & \multirow{3}{*}{ Postest } & $\begin{array}{l}\text { Correlation } \\
\text { Coefficient }\end{array}$ & $.604^{* * *}$ & 1.000 \\
\hline & & Sig. (2-tailed) & .005 & \\
\hline & & $\mathrm{N}$ & 20 & 20 \\
\hline \multicolumn{5}{|c|}{ **. Correlation is significant at the 0.01 level (2-tailed). } \\
\hline
\end{tabular}

Sumber: Hasil Analisis, 2021

Berdasarkan Tabel. 4 Korelasi Spearman rhoantar nilai pree test dan nilai post test terlihat bahwa korelasi peringkat Spearmen adalan $\mathrm{rs}=0.604$. Karena P-value $=0,005$ lebih kecil dari nilai $\alpha=0,01$ maka $\mathrm{H}_{0}: \rho s=0$, ditolak dan $\mathrm{H}_{0}: \rho \neq 0$, diterima. Hal ini menunjukan terdapat korelasi positif dan signifikan pengetahuan masyarakat tani sebelum diberikan penyuluhan dan setelah diberikan penyuluhan. Penyuluhan pencemaran udara di dalam ruangan memberikan pengaruh yang signifikan terhadap peningkatan pengetahuan masyarakat di Desa Tridana Mulya.

\section{KESIMPULAN}

Pengetahuan petani tentang pencemaran udara dalam rumah pada tangga sebelum dilakukan kegiatan penyuluhan mayoritas masih tergolong rendah. Namun, setelah diadakan kegiatan penyuluhan pengetahuan petani mengalami perubahan yang dikategorikan baik menjadi $70 \%$, sedang $25 \%$ dan yang dikategorikan rendah hanya 5\%. Uji korelasi Spearman menunjukkan $\mathrm{P}_{- \text {value }}=$ 0,005 lebih kecil dari nilai $\alpha=0,01$ maka $_{0}: \rho s=0$ ditolak artinya terdapat hubungan yang positif dan signifikan pengetahuan remaja tani sebelum diberikan penyuluhan dan setelah diberikan penyuluhan. Penyuluhan pencemaran udara pada skala rumah tangga memberikan pengaruh yang signifikan terhadap peningkatan pengetahuan masyarakat tani di Desa Tridana Mulya.

\section{DAFTAR PUSTAKA}

Carvalho, R.L., Lindgren, R., García-López, N., Nyambane, A., Nyberg, G., Diaz-Chavez, R., Boman, C., 2019. Household air pollution mitigation with integrated biomass/cookstove strategies in Western Kenya. Energy Policy 
131,168-186.

https://doi.org/10.1016/j.enpol.2019.04.026

Chowdhury, S., Dey, S., Guttikunda, S., Pillarisetti, A.,

Smith, K.R., Di Girolamo, L., 2019. Indian

annual ambient air quality standard is achievable by completely mitigating emissions from household sources. Proc. Natl. Acad. Sci. 116,10711-10716.

https://doi.org/10.1073/pnas. 1900888116

Conibear, L., Butt, E.W., Knote, C., Arnold, S.R., Spracklen, D.V., 2018. Residential energy use emissions dominate health impacts from exposure to ambient particulate matter in India. Nat. Commun. 9, 617. https://doi.org/10.1038/s41467-018-02986-7

Estévez-García, J.A., Schilmann, A., RiojasRodríguez, H., Berrueta, V., Blanco, S., Villaseñor-Lozano, C.G., Flores-Ramírez, R., Cortez-Lugo, M., Pérez-Padilla, R., 2020. Women exposure to household air pollution after an improved cookstove program in rural San Luis Potosi, Mexico. Sci. Total Environ. 702,134456 .

https://doi.org/10.1016/j.scitotenv.2019.1344 56

Fandiño-Del-Rio, M., Kephart, J.L., Williams, K.N., Moulton, L.H., Steenland, K., Checkley, W., Koehler, K., 2020. Household air pollution exposure and associations with household characteristics among biomass cookstove users in Puno, Peru. Environ. Res. 191, 110028. https://doi.org/10.1016/j.envres.2020.110028

Gibbs-Flournoy, E.A., Gilmour, M.I., Higuchi, M., Jetter, J., George, I., Copelan, L., Dye, J.A., 2018. Differential exposure and acute health impacts of inhaled solid-fuel emissions from rudimentary and advanced cookstoves in female CD-1 mice. Env. Res Publ Health 15, 1936.

Grajeda, L.M., Thompson, L.M., Arriaga, W., Canuz, E., Omer, S.B., Sage, M., Azziz-Baumgartner, E., Bryan, J.P., McCracken, J.P., 2020. Effectiveness of Gas and Chimney Biomass Stoves for Reducing Household Air Pollution Pregnancy Exposure in Guatemala: Sociodemographic Effect Modifiers. Int. J. Environ. Res. Public. Health 17, 7723. https://doi.org/10.3390/ijerph 17217723

Ishak, N.I., Hadi, Z., 2020. Edukasi Dampak Polusi Udara Terhadap Kesehatan Di Desa Berangas Timur 7. Prosiding Hasil-Hasil Pengabdian kepada Masyarakat Tahun 2020 Dosen-dosen Universitas Islam Kalimantan, 336-342

Islam, M.M., Wathore, R., Zerriffi, H., Marshall, J.D., Bailis, R., Grieshop, A., 2021. In-use emissions from biomass and LPG stoves measured during a large, multi-year cookstove intervention study in rural India. Sci. Total Environ. $\quad 758, \quad 143698$. https://doi.org/10.1016/j.scitotenv.2020.1436 98

Kusumaningrum, N., Aji, A., Hardati, P., 2020. Tingkat Pengetahuan Mahasiswa Dalam Mendukung UNNES Mewujudkan Visi Berwawasan Konservasi Serta Faktor Yang Menyebabkan Tinggi RendahnyaPengetahuan Mahasiswa. Edu Geographi 8(1).http://journal.UNNES.ac.id/sju/index.ph p/edugeo

Menghwani, V., Zerriffi, H., Dwived, P., Marshall, J.D., Grieshop, A., Bailis, R., 2019. Determinants of cookstoves and fuel choice among rural households in India. EcoHealth $16,21-60$.

Pope, D., Smith-Sivertsen, T., Lie, R.T., Bakke, P., Balmes, J.R., Bruce, N.G., 2015. Exposure to household air pollution from wood combustion and association with respiratory symptoms and lung function in nonsmoking women: results from the RESPIRE trial, Guatemala. Env. Health Perpect 123, 285292.

Pratiti, R., Vadala, D., Kalynych, Z., Sud, P., 2020. Health effects of household air pollution related to biomass cook stoves in resource limited countries and its mitigation by improved cookstoves. Environ. Res. 186, 109574. https://doi.org/10.1016/j.envres.2020.109574

Quansah, R., Semple, S., Ochieng, C.A., Jufekar, S., Arma, F.A., Luginaah, I., Eminah, J., 2017. Effectiveness of interventions to reduce household air pollution and/or improve health in homes using solid fuel in low-and-middle income countries: a systematic review and meta-analysis. Env. Int 103, 73-90.

Rajkumar, S., Young, B.N.,Clark, M.L., Benka-Coker, M.L., Bachand, A.M., Brook, R.D., Nelson, T.L., Volckens, J., Reynolds, S.J., L’Orange, C., Good, N., Koehler, K., Africano, S., Osorto Pinel, A.B., Peel, J.L., 2019. Household air pollution from biomass-burning cookstoves and metabolic syndrome, blood lipid concentrations, and waist circumference in 
Honduran women: A cross-sectional study. Environ. Res. 170, 46-55. https://doi.org/10.1016/j.envres.2018.12.010

Ranathunga, N., Perera, P., Nandasena, S., Sathiakumar, N., Kasturiratne, A., Wickremasinghe, A.R., 2021. Effects of indoor air pollution due to solid fuel combustion on physical growth of children under 5 in Sri Lanka: A descriptive cross sectional study. PLOS ONE 16, e0252230. https://doi.org/10.1371/journal.pone.0252230

State of Global Air, 2019. State of Global Air 2019: A special report on global exposure to air pollution and its disease burden.

Tagle, M., Pillarisetti, A., Hernandez, M.T., Troncoso, K., Soares, A., Torres, R., Galeano, A., 2019. Monitoring and modeling of household air quality related to use of different Cookfuels in Paraguay. Indoor Air 29, 252-262. https://doi.org/10.1111/ina.12513

The World Bank, 2014. Berita: Tungku Bersih Untuk Indonesia yang Lebih Sehat.

WHO, 2018. Household air pollution and health.

YDD, 2014. Dampak-Polusi-Udara-Dalam-RuangPada-kesehatan.html. Yayasan Dian Desa. 